\title{
E-Lifestyle And Internet Advertising Avoidance
}

\author{
Widarto Rachbini ${ }^{1}$, Iha Haryani Hatta ${ }^{2}$ \\ ${ }^{1}$ Sekolah PascasarjanaUniversitasPancasila, Jakarta \\ ${ }^{2}$ Fakultas Ekonomi dan Bisnis Universitas Pancasila, Jakarta \\ Email :widarto@univpancasila.ac.id
}

\begin{abstract}
E-lifestyle behavior towards avoiding internet advertising needs to be known to design an advertisement on the internet, so that the tendency of avoiding internet advertising can be reduced.Therefore, research on e-lifestyle and internet advertising avoidance is needed which aims to find out the influence of each e-lifestyle on Internet advertising avoidance and the behavior of each e-lifestyle towards Internet advertising avoidance activities. The population of this study is Internet users. A sample of 200 Jakarta residents were selected by purposive sampling technique. Data were analyzed using Structural Equation Modeling (SEM). The results obtained after the data were analyzed show that need-driven, interest-driven, entertainment-driven, sociability-driven, and novelty-driven influence the avoidance of Internet advertising. But Importancedriven and concern-driven e-lifestyle have no influence. In addition, entertainment-driven e-lifestyle has the largest factor loading value on average. This indicates that the majority of respondents are entertainment-driven in using the Internet everyday.
\end{abstract}

Keywords: e-lifestyle, Internet advertising avoidance

\section{INTRODUCTION}

Internetworldstats (2018) reveals that Internet users in Indonesia in December 2017 reached more than 143 million or $7.1 \%$ of the total Internet users in the Asian continent. Meanwhile, the results of a survey conducted by Hootsuite (2018) revealed that the preference of the Indonesian people in using the Internet was that the majority visited social media using smart phones. The majority of Internet users in Indonesia in 2016, who actively used the Internet, accessed their Internet on mobile phones and computers by 67.2 million people or $50.7 \%$, followed by access via mobile phones as many as 63.1 million people or $47,7 \%$, and the remaining $1.7 \%$ only accessed via a computer or 2.2 Internet users in Indonesia.

The Internet has become a part of everyday life that cannot be separated from modern human life since the beginning of Internet commercialization in the mid-1990s. Internet is used to help it users meet their living needs, includinginformation searches, communication in social networks that function as electronic proxies from real life. This behavior indicates that an e-lifestyle characteristic of internet users can function as a foundation for building effective and interesting Internet advertisements (Koshksarayet. Al., 2015). On the other hand, the phenomenon of the digital economy is growing because business practitioners have used social media as a way to promote (Rachbini, 2018). Internet can also be a convergent medium, meaning that it can function as communication media, such as television, radio, newspapers, magazines, billboards, and direct mail (Cho and Cheon, 2004). Through the internet, users can utilize the information from the communication media and communicate with other internet users. The internet can help manufacturers and advertisers to access users directly and faster 
than using traditional media channels (Koshksarayet. Al., 2015). Also obtained information that Internet advertising or digital advertising in Indonesia continues to grow very rapidly. E-marketer, (2015) predicts that advertising spending in Indonesia will continue to grow until 2019, especially Internet advertising which has become a necessity for producers or companies in promoting their products and services. Internet advertising spending in Indonesia will continue to experience significant growth where in 2019 there will be an increase of $146.75 \%$ or $\$ 7.60$ billion compared to advertising spending in 2017 which only reached $\$ 3.08$ billion. See Table 1 .

Table 1.Internet and Mobile Internet Advertising Spending in Indonesia (In Billions of Dollars

\begin{tabular}{llccc}
\hline \multirow{2}{*}{ No } & \multirow{2}{*}{ Advertising Type } & \multicolumn{3}{c}{ Year } \\
\cline { 3 - 5 } & & 2017 & 2018 & 2019 \\
\hline 1 & Internet Advertising & 2,34 & 3,51 & 4,92 \\
2 & Mobile Internet & 0,74 & 1,49 & 2,68 \\
& Total & 3,08 & 5,00 & 7,60 \\
\hline
\end{tabular}

Source: E-marketer, (2015)

However, the total advertising expenditure and the amount of revenue is not directly proportional to the statistical report which shows that the number of click through rates or often is defined as a comparison or percentage of the number of Internet ads clicked by website visitors (Setyobudianto, 2015) which continues to decline. Nielsen, (2000) revealed that in 1995 the number of click through rates reached 2\%, whereas in 2008 the figure decreased to only 0.3\% MediaPost, 2008; Cho and, 2004).

Another phenomenon is the increasing blindness of website visitors or Internet users to the banners in the Internet advertising space (Cho and Cheon, 2004), as well as Internet content avoidance, active blocking such as against pop-up advertisements (Koshksarayet. al., 2015). Internet advertising avoidance occurs when Internet users consciously and deliberately try to avoid various stimuli (advertisements) (Tellis, 1997). Internet advertising avoidance is defined as the overall preventive action taken by internet users to eliminate advertisements on the internet in their own ways (Speck and Elliot, 1997). Advertisers must anticipate various reasons for avoiding internet advertising either covertly or openly so that the advertisers can develop more effective strategies to communicate companies or messages from products to a target market (Koshksarayet. al., 2015). There are three types of internet advertising avoidance, namelycognitive, affective, and behavioral avoidance (Cho and Cheon, 2004). E-lifestyle of internet users is one of the factors that influence internet users to do internet advertising avoidance. The lifestyle feature provides information to advertisers regarding information on what internet users want and need, so advertisers can meet what internet users want and need in a complex and competitive market (Kamakura and Wedel, 1995). According to Koshksarayet. al., (2015), targeted advertising will be more effective and can reduce the Internet advertising avoidance, as well as generate a better click through rate ratio.

Based on the above discussion, it is important to conduct research on e-lifestyle and internet advertising avoidance which aims to find out the influence of each e-lifestyle on internet advertising avoidance, and the behavior of each e-lifestyle towards Internet advertising avoidance activities. 


\section{THEORETICAL REVIEW}

Yu's (2011) research found that e-lifestyle is reflected in seven dimensions namely need-driven, interest-driven, entertainment-driven, sociability-driven, perceived importance-driven, uninterested or concern-driven and novelty-driven. Lifestyle classification serves to identify characteristics that are useful for advertisers in precisely targeting consumers and designing better internet advertising (Koshksarayet. Al., 2015).In addition, each lifestyle of internet users will indicate differences in their behaviors (Yang, 2004). Consumers with various e-lifestylewill show different reactions to advertisement on internet (Koshksaray et. al., 2015).

Need-driven e-lifestyle.This need-based e-lifestyle characteristic is reflected in the lifestyle of a person whose activities are mostly developed through the internet. Internet services are a tool to meet what people need, provide comfort, efficiency, and assistance in completing their tasks or jobs.According to Kaye and Johnson, (2001); Papacharissi and Rubin, (2000), there are four main motivations for using the internet, namely information, convenience, entertainment, and social interaction. To a person, all of the motivations need a long time to utilize internet and visit various kinds of sites(Koshksaray et. Al., 2015). Ko et al., (2005) show that Internet users who are motivated because of information is most likely involved in the interaction between humans and the messages conveyed. Internet users who have entered cyberspace with comfort and are motivated because of social interaction is usually involved in the interaction between humans and humans. Therefore, every individual who utilizes internet with a different motivation will show a different e-lifestyle. Motivated users (Ko et al., 2005) or goal-oriented users (Cho and Cheon, 2004) attempt to meet their needs on the Internet with little attention to minor issues. Yu, (2011) said that internet and other communication information technologies are utilized by those individuals who are motivated to meet their goals for all of their activities such as obtaining information, news, shopping, banking, and financial services. In general, these services greatly affect their daily lives and work. Individuals who are in the need-driven e-lifestyle group benefit more from the increased time spent using the Internet. Thus, individuals who use the internet for certain purposes will try to avoid any factor, such as advertisements that prevent them from accessing the Internet (Koshksaray et. Al., 2015). According to Cho and Cheon, (2004), the main way to solve the reluctance to access the intrnet is internet advertising avoidance. Need-based internet users will, in utilizing the internet, ignore internet advertisement because such advertisement inhibits their attempts to meet their goals. Individuals with this basis avoids internet advertisement because they have a high level of involvement in various tasks completion through the Internet . (Koshksaray et. al., 2015).

Interest-drivene-lifestyle.Individuals who show interest-driven e-lifestyle will spend much time to follow the latest advancements in various services, interact and learn and engage with the latest Internet technology. Individuals with this basis consider that internet services are important for their life or, in other words, the individuals are the influencers of communication and information technology (ICT) (Yu, 2011). Individuals who show a character with this basis are active users of various sophisticated services and updated ICT services. However, these individualsalso eagerly avoid useless internet 
services.Thus, individuals like this are able to show their acceptance and rejection of internet advertising (Koshksaray et. al., 2015).

Entertainment-drivene-lifestyle.Individuals who are driven by entertainment will utilize internet services for their activities such as sepertimusic, movies, sports matches, games, making friends and having fun (Yu, 2011). Although individuals in e-lifestyle participate on the internet to get entertainment and enjoy their hobbies, their responseto internet advertising is very dependent on the usefulness of the advertisement (Ko et al., 2005). Avoidance of internet advertising by these individuals is based on effective aspects (Koshksaray et. al., 2015).

Sociability-driven e-lifestyle. E-lifestyleof this kind is in every individual. Individualswith this basis use internet services and electronics to develop online communication in an environment. Menurut Yu (2011), these individuals consider internet as a tool to expand their activities such as distribution of information, trust, delivering ideas, and actively participating in social activities. According to Ko et al., (2005),internet users with this basis visit websites with a hope that they can interact socially, that is communicating with other visitors of the same site. There are two kinds of interaction on that site those are human-message and human-human interactions. Individuals who interact in this way will consider website content more positively. Human-human interaction on a website is more active compared to human-message interactions (Ko et al., 2005). Results of a research carried out by Koshksaray et. al., (2015) showed that,in gathering information on varous products,internet users with sociability-driven $e$ lifestylebasis believe word-of-mouth advertisementsrather than tradisional advertising. Through chat room, feedback sites, and blog, these individuals exchange belief and ideas to get information on various products dan services so that their beliefs and attitudes regarding such information are established.

Perceived importance-driven e-lifestyle.Individuals with this basis consider that internet can give positive effects on economic activities, society, education, and individual life. This positive expectation emphasizes the importance of the Internet to expand economic activities, social and educational activities in people's lives. Individuals like this make use of Internet services and feel safe by getting the latest information, so they get significant personal benefits (Yu, 2011). Individuals with e-lifestyle like this also utilize the internet and other information and communication technologies as the key factor that supports the progress at the macroeconomic level, and show a positive attitude towards it. They continue to seek personal and professional benefits, and actively consider their own successes (Yu, 2011). It is expected, later, individuals who are classified as e-lifestyle like this assess Internet advertising as a barrier to achieving their goals (Koshksaray et. al., 2015).

Uninterested or concern-driven e-lifestyleand Internet advertising avoidance.According to $\mathrm{Yu},(2011)$, described that with e-lifestyle like this do not have a positive attitude towards internet services. They think the expansion of internet services puts more pressure on the community and have a negative impact on education and society. As such, they show negative opinions and projections on Internet services in people's lives. Since online communication and interaction between individuals is carried 
out without body and emotional movements, they consider space in cyberspace as an obstacle in communication. Therefore, they use Internet services or communication and information technology only during emergencies ( $\mathrm{Yu}, 2011)$. The negative attitude of Internet users like this is very strong, it has been proven by $\mathrm{Yu},(2011)$ in his research.

Novelty-driven e-lifestyle.Individuals with this basis are ready to share information about new knowledge in matters related to Internet services and information communication technology (ICT) with others. Acquiring and sharing the knowledge about ICT trends and developments is very important for them and Internet users belonging to this group spend a lot of time anticipating these trends and developments. Novelty or something new in adopting new technologies and the challenges they face, are very important and give satisfaction when they are able to reach and have the ability to use the latest services or technology (Yu, 2011). Internet users in the category of novelty-driven e-lifestyle have expectations to avoid Internet advertising (Koshksaray et. al., 2015).

Thinking Framework.Based on various theories and a number of previous studies above, the thinking framework developed and the seven hypotheses tested in this study are as follows:

$\mathrm{H} 1$ :The influence of Need-driven e-lifestyle on Internet Advertising Avoidance $\mathrm{H} 2$ :The influence of Interest-driven e-lifestyle on Internet Advertising Avoidance H3 :The influence of Entertainment-driven e-lifestyle on Internet Advertising Avoidance

$\mathrm{H} 4$ :The influence of Sociability-driven e-lifestyle on Internet Advertising Avoidance

H5 :Influence of Importance-driven e-lifestyle on Internet Advertising Avoidance

H6 :The influence of Uninterested or concern-driven e-lifestyle on Internet Advertising Avoidance

$\mathrm{H} 7$ :The influence of Novelty-driven e-lifestyle on Internet Advertising Avoidance

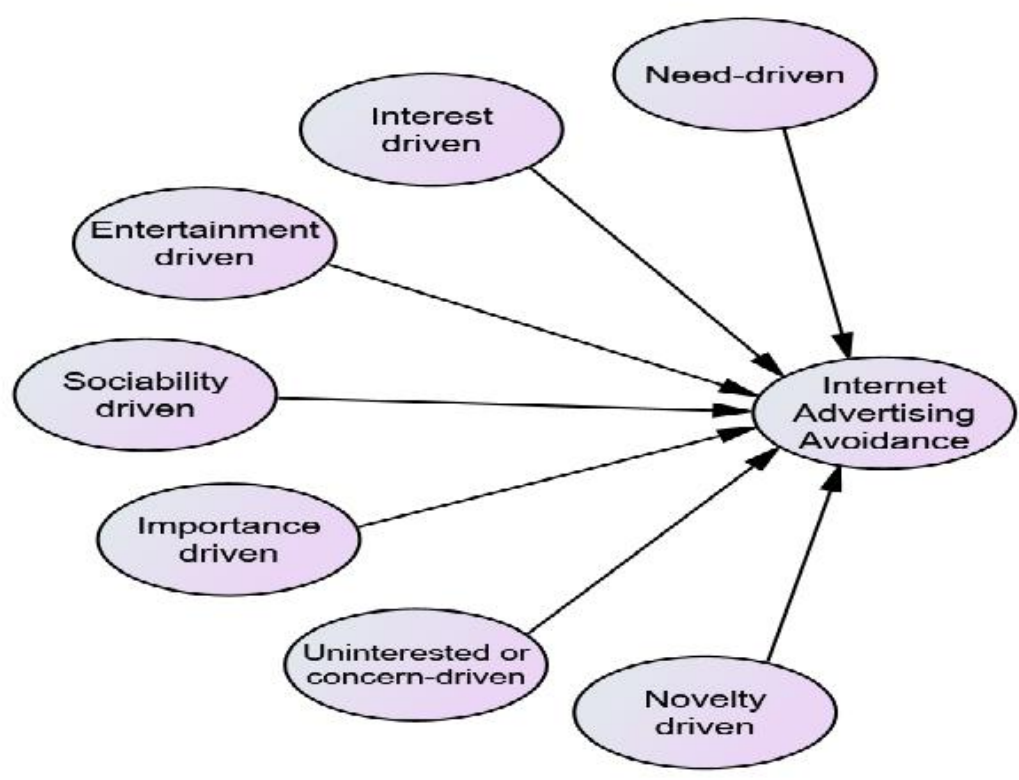

Figure 1.Thinking Framework 


\section{METHODS}

Data collection procedure. The data used in this study is primary dataas well as secondary data. The primary data is acquired through direct collection of information by researchers to answer the problem or research objectives. The sampling method is nonprobability sampling with sampling techniques, namely purposive sampling. Purposive Sampling Technique is a sampling technique in which a sample is chosen based on certain considerations or criteria (Sekaran, 2003). The data collected is a sample of a number of populations selected based on several criteria, namely active Internet users, and at least using the Internet for two hours per day. The secondary data is acquired from books and journals.

The measuring instrument used is questionnaire consisting of a closed-end statement with alternative answers according to Likert Scale 1 - 5. Scale $1=$ strongly disagree, 2 = disagree, $3=$ neutral $/$ doubtful, $4=$ agree, and $5=$ strongly agree. Questionnaires were collected online with the help of Google Docs.

Before the results of data processing were analyzed, validity and reliability were tested. According to Hair et al (2010) that Cronbach's Alpha of each construct is greater than 0.70 . This shows that all constructs in this study can be said to be reliable or the answers from all respondents are consistent. In addition, to find out whether the measuring instrument is valid or not, seen from the value of each factor loading of each indicator or measuring instrument for each variable in this study. Indicator is valid if the indicator has a factor loading value $>0.60$.

To answer research questions about the relationship between variables, structural equation models are used. In this case the test model will use the help of SmartPLS v 3.0M software. SmartPLS is used with Partial Least Square (PLS) approach. PLS is an alternative method of estimating models to manage Structural Equation Modeling (SEM). Sample size plays a very important role in estimating and interpreting research results. According to Hair et al., (2010), the results of statistical tests are very sensitive to the size of the sample. The exact size of the sample size in most scientific studies ranges from 30 to 500 respondents (Sekaran, 2003).Meanwhile, according to Sofyan (2014), if the p value is equal to $* * *(0,000)<0.05$, then the hypothesis will be rejected and the alternative hypothesis will be accepted, meaning that there is an influence between the two variables.

\section{RESULTS AND DISCUSSION}

Respondents Profile. From the results of data processing related to the characteristics or profile of respondents, the results show that out of 200 Internet users in Jakarta, the majority of respondents are active Internet users (100\%), have a frequency of using the Internet more than 5 hours per day (67.35\%), female sex (52.3\%), has a final education S1 (76\%), and domiciled in Jakarta (72.1\%), and the majority are private employees $(66.1 \%)$ with monthly expenditure of Rp. 4.000.000- Rp. 8.000.000 (43\%).

Based on Table 2, it can be seen that all of these indicators can be said to be valid or have a correlation with each of the variables, because all indicators have a factor loading value $>0.60$. In addition, all variables in this study are said to be reliable, because all of these variables have Cronbach's Alpha greater than 0.70 . 
Table 2. Validity and Reliability Test Result

\begin{tabular}{ccc}
\hline Indicator & Factor Loading & Cronbach Alpha \\
\hline Need-driven e-lifestyle & & 0.937 \\
\hline ND1 & 0.769 \\
ND2 & 0.788 \\
ND3 & 0.836 \\
ND4 & 0.797 \\
ND5 & 0.758 \\
ND6 & 0.770 \\
ND7 & 0.868 \\
ND8 & 0.823 \\
ND9 & 0.872
\end{tabular}

\begin{tabular}{|c|c|c|}
\hline Need-driven e-lifestyle & & 0.954 \\
\hline IDE1 & 0.882 & \\
\hline IDE2 & 0.893 & \\
\hline IDE3 & 0.921 & \\
\hline IDE4 & 0.925 & \\
\hline IDE5 & 0.900 & \\
\hline IDE6 & 0.888 & \\
\hline Entertainment-driven e-lifestyle & & 0.981 \\
\hline ED1 & 0.893 & \\
\hline ED2 & 0.951 & \\
\hline ED3 & 0.975 & \\
\hline ED4 & 0.983 & \\
\hline ED5 & 0.953 & \\
\hline ED6 & 0.974 & \\
\hline Sociability-driven e-lifestyle & & 0.952 \\
\hline SD1 & 0.906 & \\
\hline SD2 & 0.923 & \\
\hline SD3 & 0.906 & \\
\hline SD4 & 0.894 & \\
\hline SD5 & 0.948 & \\
\hline Importance-driven e-lifestyle & & 0.926 \\
\hline MPE1 & 0.891 & \\
\hline MPE2 & 0.887 & \\
\hline MPE3 & 0.859 & \\
\hline
\end{tabular}




\begin{tabular}{ccc}
\hline MPE4 & 0.921 & \\
MPE5 & 0.834 & 0.937 \\
\hline Importance-driven e-lifestyle & & \\
\hline UCE1 & 0.838 & \\
UCE2 & 0.870 & \\
UCE3 & 0.928 & 0.971 \\
UCE4 & 0.909 & \\
UCE5 & 0.907 & \\
Novelty-driven e-lifestyle & & \\
VDE1 & 0.934 & \\
VDE2 & 0.988 & \\
VDE3 & 0.934 & \\
VDE4 & 0.979 & \\
\hline Internet Advertising Avoidance & & \\
PI1 & 0.807 & \\
PI2 & 0.663 & \\
PI3 & 0.648 & \\
PI4 & 0.877 & \\
PI5 & 0.795 & 0.873 \\
PI6 & 0.800 & \\
PI7 & 0.831 & \\
PI8 & 0.673 & \\
PI9 & & \\
PI10 & & \\
\hline & & \\
\hline
\end{tabular}


Based on Figure 2, the research model stated in Table 3 can be determined. Based on Tabel 4 , it is found out that $\mathrm{R}^{2}=0,75$, meaning that the variables of need-driven, interestdriven, entertainment-driven, sociability-driven, perceived importance-driven, uninterested or concern-driven and novelty-driven contribute $75 \%$ to the clarity of Internet advertising avoidance variables. Other variables that are not present in this study can contribute $25 \%$ to the clarity of Internet advertising avoidance variables.

Table 3. Research Model

\begin{tabular}{clc}
\hline No. & \multicolumn{1}{c}{ Structural Equation } & Notes \\
\hline 1. & $\mathrm{PI}=0,22 \mathrm{ND}+0,05 \mathrm{IDE}+0,21 \mathrm{ED}+0,23 \mathrm{SD}+$ & $\mathrm{R}^{2}=0,75$. \\
& $0,21 \mathrm{MPE}+0,03 \mathrm{UCE}+0,27 \mathrm{VDE}$ & \\
\hline
\end{tabular}

Source: Processed research data

The table above shows that there are two rejected hypotheses and five accepted hypotheses. The rejected hypothesesinclude hypothesis 5 and hypothesis 6 , because the $p$ value is $\geq 0.05$.Theaccepted hypotheses include hypothesis 1 , hypothesis 2 , hypothesis 3 , hypothesis 4 , and hypothesis 7 , because the $\mathrm{p}$ value is $<0.05$.Hypothesis 1 is accepted, meaning that there is an influence of the need-driven e-lifestyle variable on internet advertising avoidance variable. The diversity of the need-driven e-lifestyle variable value and internet advertising avoidance can explain the relation between the two variables. Hypothesis 3 is accepted, meaning that there is an influence of entertainment-driven elifestyle variable on internet advertising avoidance variable. The diversity of entertainment-driven e-lifestyle variable value and internet advertising avoidance can explain the relation between the two variables. Hypothesis 4 is accepted, meaning that there is an influence of sociability-driven e-lifestyle variable on internet advertising avoidance variable. The diversity of the sociability-driven e-lifestyle variable value and internet advertising avoidance can explain the relation between the two variables. Hypothesis 7 is accepted, meaning that there is an influence of novelty-driven e-lifestyle variable on internet advertising avoidance variable. The diversity of novelty-driven elifestyle variable value and internet advertising avoidance can explain the relation between the two variables. 


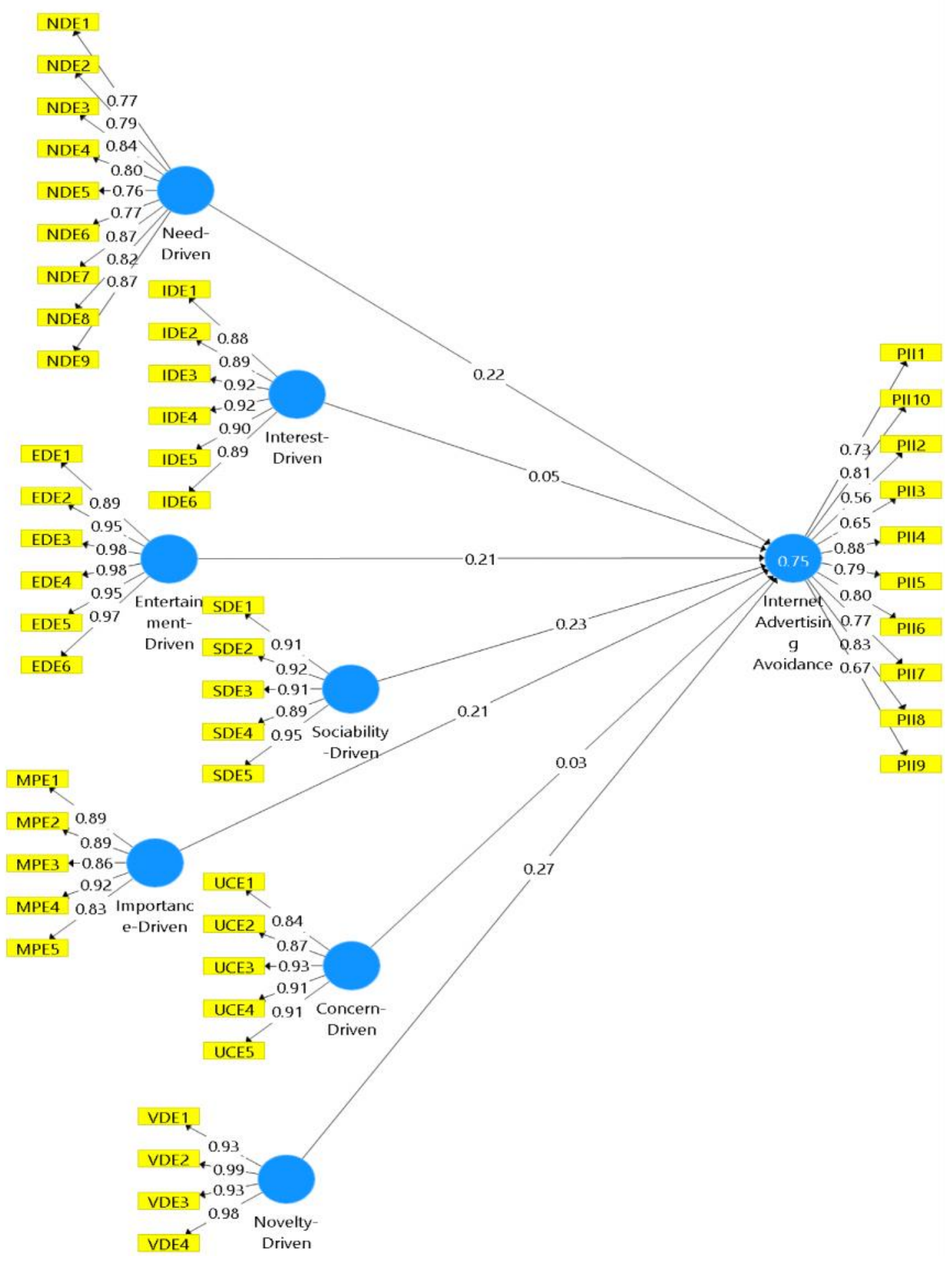

Figure 2.Full Structural Model

Source: Processed research data, (2017)

Furthermore, the results of hypotheses testing in this study are summarized in the table below, including the following: 
Table 4.Hypothesis Test Results

\begin{tabular}{|c|c|c|c|}
\hline & Hypothesis & P Values & Significance \\
\hline H1 & $\begin{array}{l}\text { The influence of need-driven e-lifestyle(ND) on } \\
\text { internet advertising avoidance (PI) }\end{array}$ & 0.000 & Significant \\
\hline $\mathrm{H} 2$ & $\begin{array}{l}\text { The influence of interest-driven e-lifestyle } \\
\text { (IDE) on internet advertising avoidance (PI) }\end{array}$ & 0.000 & Significant \\
\hline H3 & $\begin{array}{l}\text { The influence of entertainment-driven e- } \\
\text { lifestyle (ED) on internet advertising avoidance } \\
\text { (PI) }\end{array}$ & 0.000 & Significant \\
\hline $\mathrm{H} 4$ & $\begin{array}{l}\text { The influence of sociability-driven e-lifestyle } \\
\text { (SD) on internet advertising avoidance (PI) }\end{array}$ & 0.000 & Significant \\
\hline H5 & $\begin{array}{l}\text { The influence of importance-driven e-lifestyle } \\
\text { (MPE) on internet advertising avoidance (PI) }\end{array}$ & 0.197 & Not Significant \\
\hline H6 & $\begin{array}{l}\text { The influence of Uninterested or concern- } \\
\text { driven e-lifestyle (UCE) on internet advertising } \\
\text { avoidance (PI) }\end{array}$ & 0.444 & Not Significant \\
\hline $\mathrm{H} 7$ & $\begin{array}{l}\text { The influence of novelty-driven e-lifestyle } \\
\text { (VDE)on internet advertising avoidance (PI) }\end{array}$ & 0.000 & Significant \\
\hline
\end{tabular}

Whereas hypothesis 5 is rejected, meaning that there is no influence of perceived importance-driven e-lifestyle variable on internet advertising avoidance variable. The diversity of perceived importance-driven e-lifestyle variable value and internet advertising avoidance variable cannot explain the relation between the two variables. Hypothesis 6 is rejected, meaning that there is no influence of uninterested or concern-driven e-lifestyle variable on internet advertising avoidance variable. The diversity of uninterested or concern-driven e-lifestyle variable value and internet advertising avoidance cannot explain the relation between the two variables.

\section{DISCUSSION}

A need-driven e-lifestyle has proven to effect on Internet advertising avoidance. Based on these findings, individuals with this basis do internet advertising avoidance in a behavioral and emotional manner. This is in accordance with the results of a previous research carried out byKoshksaray et. al.,(2015) revealed that individuals with lifestyles like this are involved in the utilization of the internet as a way to achieve their personal wants and occupational needs, and actively avoid internet advertising. Banner and pop-up advertisement displays are notattractive to this type of internet users, so that such advertisements are ignored. In addition, internet users who fall into the category of needdriven e-lifestyle emotionally show negative attitudes towards internet advertising and the desire to access the internet free of advertising. The biggest factor that influences the avoidance of internet advertising in need-driven e-lifestyle is because of the barrier to 
perceived goals (Cho and Cheon, 2014). For example, an organization or company that has a target market, namely individuals with this basis and use the Internet as a tool to facilitate their personal wants and occupational need, thus the organization must be very concerned about web design and display of advertisements on the website that. Therefore, organizations or companies must target their ads to meet their needs, desires, and goals. If this is considered or adopted, it will help improve the effectiveness of Internet advertising and strengthen the brand image. Those two things will be maintained and well-embedded in the minds of customers (Hanaf zadeh and Behboudi, 2012).

Previous research states that individuals who are classified as interest-driven elifestyle emotionally avoid Internet advertising. This is in line with the results of this study which shows that there is a positive influence of interest-driven e-lifestyle on Internet advertising avoidance. Koshksaray et al., (2015) revealed that although people in the interest-driven e-lifestyle category spend a lot of time using the Internet, they tend to ignore any Internet advertisements that they consider unattractive. Thus, it is recommended that companies or organizations that target individuals with this basis should use a more creative advertisement display so that they can make a difference in the context of online-based advertising. Basically, individuals with this basis continue to look for interesting and new products and services in the information and communication technology (ICT) domain, so each ad must reflect its own creativity. Individuals with lifestyles like this are the main market segments when launching the latest ICT products and services, because they are usually early adopters of the latest technology (Koshksaray et. al., 2015).

Individuals belonging to entertainment-driven e-lifestyle use internet services by being driven by various entertainment activities such as listening to music, watching video, and enjoying browsing the Internet as media of entertainment. Basically, internet users with this basis are involved in using the Internet as an entertainment media and enjoy using the internet as a major part of their leisure activities. The results of this study indicate that there is a positive influence of entertainment-driven e-lifestyle on Internet advertising avoidance. Koshksaray et. al., (2015) states that individuals who have this type of e-lifestyle explicitly avoid Internet advertising. Yu, (2011) revealed that entertainmentdriven e-lifestyle can be a very interesting segment when the design and communication of advertising content via the Internet is delivered correctly so that it can increase the percentage of click through rate and ultimately conversion or purchase. Therefore, Koshksaray et. al., (2015) in his research strongly recommends that companies or organizations must have entertainment value in every advertisement delivered via the Internet.

Furthermore, researchers suspect that sociability-driven e-lifestyle has a positive and significant effect on Internet advertising avoidance. The results of this study indicate that there is a positive influence of sociability-driven e-lifestyle on Internet advertising avoidance. This is in line with previous research conducted by Ko et al., (2005) which revealed that individuals with this basis tend to typically seek interaction with other humans or are often referred to as the concept of human-human interaction and they prefer to share interests and beliefs through the Internet, and engage in a wider social network to start online conversations with other Internet users. People in these lifestyles doubt internet advertising and have a tendency to gather information from other consumers before purchasing a product or service. Thus, internet advertising banners, or other types of advertising do not appeal to individuals in sociability-driven e-lifestyle. Koshksaray et. 
al., (2015) states that traditional Internet advertisements such as banners or pop-up ads do not appeal to individuals belonging to sociability-driven e-lifestyle. Therefore, it is recommended that strategies involving key opinion leaders are needed in a social online platform that functions to encourage word-of-mouth from each individual with this basis.

The results of this research indicate that the importance-driven e-lifestyle has no influence on internet advertising avoidance. This is because individuals who belong to elifestyle like this judge the internet advertising as an obstacle in their way to achieve their goals (Koshksaray et al., 2015). According to Yu (2011), individuals with this basis think that the internet can have a positive impact on economic activities, society, education, and individual life. This positive expectation emphasizes the importance of the internet to expand economic activities, social and educational activities in people's lives. Individuals like this make use of Internet services and feel safe by getting the latest information, so internet can help increase personal benefits (Yu, 2011). Individuals with e-lifestyle like this also utilize the internet and other information and communication technologies as the main media towards improvement at the macroeconomic level, and show a positive attitude towards it. They keep using internet to get personal benefits dan meet their occupational needs.

There is no significant influence of uninterested or concern-driven e-lifestyle on the Internet advertising avoidance. This consistently supports the theory expressed by $\mathrm{Yu}$, (2011) which states that individuals with uninterested or concern-driven e-lifestyle do not have a positive attitude towards the internet and think that the expansion of Internet services can put more pressure on society. Internet users with this basis think that internet services have a negative influence on education and society. As such, the individuals show negative opinions and ideas on internet services in people's lives. Those individuals judge that online communication and interaction between individuals is carried out without body and emotional movements, they consider space in cyberspace as an obstacle in communication. Therefore, they use Internet services or communication and information technology only during emergencies (Yu, 2011).

The idea that most individual behavior in the novelty-driven e-lifestyle group shows a very strong avoidance of Internet advertising (Koshksaray et. Al., 2015). The results of this study consistently prove that there is a novelty-driven e-lifestyle positive influence on Internet advertising avoidance and these results support also the results of previous research because individuals with lifestyle like this are only motivated to access and obtain information regarding the latest Internet trends, so individuals in novelty-driven e-lifestyle avoids Internet advertising if these ads are not in line with the latest online trends and Internet users in the category of novelty-driven e-lifestyle have expectations to avoid Internet advertising (Koshksaray et. al., 2015). Therefore, advertisements targeted at individuals like them must prioritize updated mechanisms and information. Acquiring and sharing the knowledge about trends and developments in information and communication technology is very important for them and Internet users who belong to this group spend a lot of time anticipating these trends and developments. Novelty or something new in adopting new technologies and various challenges they face, are very important and give satisfaction when they are able to reach and have the ability to use the latest services or technology (Yu, 2011).

In the era of e-commerce and social commerce, individuals get an easy way to share knowledge, experience, and information about products and services to people in their neighborhood or close friends. Consumers use social media to share information, 
knowledge, and experiences to their friends in groups and communities. This progress makes consumers become part of the process of value creation for business through social support on the Internet (Rachbini, 2017). Thus, practitioners also not only focus on online ad placement, but activation on social media must also be optimized and continue to strive to increase consumer involvement. In addition, marketers must also consider the estimation of each online-based advertising achievement by measuring estimates related to the number of clicks, impressions, and the occurrence of online transactions. This must be done in order to get the ideal and beneficial return on investment (ROI) for the company, as well as optimal exposure for the brand being promoted. In addition, the selection of promotional media should also be consulted first with third parties such as media agencies or media buyers who are experts and know the media profile in a comprehensive and detailed manner.

\section{CLOSING}

E-lifestyle behavior of internet users has an influence on the internet advertising avoidance. Variables of Need-driven e-lifestyle, Interest-driven e-lifestyle, Entertainmentdriven e-lifestyle, Sociability-driven e-lifestyle and Novelty-driven e-lifestyle have an effect on the Internet advertising avoidance. While the Importance-driven e-lifestyle variable, and Novelty-driven e-lifestyle do not affect the Internet Advertising avoidance. The contribution of these variables by $75 \%$ provides clarity on Internet advertising avoidance variables.

This finding serves to provide benefits for advertisers and marketers when they are going to design Internet advertisements, so they can determine the messages and media used in accordance with the characteristics of targeted consumers or Internet users. It also aims to provide understanding related to advertising consumption, avoidance, rather than just aspekdemographi. Iklan internet yang efectifdanmenarikbagipengguna internet dapatdibuatuntukdipublikasikandenganselalumemperhatikanbeberapaperilakue-lifestyle yang telahdijabarkanpadapenelitianini.

\section{REFERENCES}

Asosiasi Penyelenggara Jasa Internet Indonesia (APJII). (2016). Infografis penetrasi pengguna internet Indonesia. <http://bit.ly/2jWgb44>

Cho, C., Cheon, H., (2004). "Why do people avoid advertising on the Internet?", $J$. Advert. 33 (4), 89-97.

E-Marketer.(2015). Indonesia Boasts Highest Digital, Mobile Internet Ad Growth in World. <https://www.emarketer.com/Article/Indonesia-Boasts-Highest-DigitalMobile-Internet-Ad-Growth-World/1012341>

Hair, J.F., Black, W.C., Babin, B.J., Anderson, R.E. (2010). Multivariate Data Analysis, 7th edn. Prentice Hall.

Hanafizadeh, P., Behboudi, M., (2012). Online Advertising and Promotion: Modern Technologies for Marketing. IGI Global, Hershey, PA; pp. 1-430. <http://dx.doi.org/10.4018/978-1-46660-885-6>

Hootsuite. (2018). "Indonesia Digital Landscape: A Snapshot Of the Country's Key Digital Statistical Indicators". 
Internetworldstats (2018). Retrieved from: https://www.internetworldstats.com/stats.htm Kamakura, W.A., Wedel, M., 1995. Life-style segmentation with tailored interviewing.J. Mark. Res. 32 (3), 308-317.

Kaye, B.K., Johnson, T.J., (2001). A Web for All Reasons: Uses and Gratifications of Internet Resources for Political Information. Paper presented at the Association for Education in Journalism and Mass Communication Conference, Washington, DC, August.

Kelly, L., Kerr, L., Drennan, J., (2010). Avoidance of advertising in social networking sites: the teenage perspective. J. Interactive Advert. 10 (2), (accessed 05.12).

Ko, H., Cho, C., Roberts, M., (2005). "Internet uses and gratifications structural equation model of interactive advertising". Jurnal Advert. 34 (2), 57-70.

Koshksaray A., Franklin D., Hanzaee, (2015). The relationship between e-lifestyle and Internet advertising avoidance.Australian and New Zealand Marketing Academy. Published by Elsevier Ltd; 1441-3582.

MediaPost, (2008). Beyond the Click through. 01/14/2008 by Jeff Hirsch, Monday, January14,2008. <www.mediapost.com/publications/?fa=Articles...art_aid>.

Nielsen, J., (2000). Methodology Weaknesses in Poynter Eyetrack Study. (May 14). <www.useit.com/alertbox/20000514_weaknesses.html>.

Papacharissi, Z., Rubin, A.M., (2000). Predictors of Internet use. J. Broadcast. Electron. Media 44 (2), 175-196.

Rachbini, W. (2017). Peran Social Support Terhadap Relationship Quality dan Social Commerce Intention

Rachbini, W. (2018). “The Impact of Service Brand Evaluation, Customer Engagement on Brand Trust and Brand Loyalty - Study on Culinary Business as Part of Creative Economy Industry in Indonesia”. International Journal of Marketing and Human Resource Management (IJMHRM), 9 (1), 01-17.

Sekaran, Uma. (2003). "Research Methods For Business - A Skill Building Approach", Fourth Edition. John Wiley dan Sons, Inc.

Setyobudianto. (2015). Pengertian Dasar PV, Impression, Filled Rate, CTR, CPC, CPMdan eCPM di Dunia Digital Advertising. <http://www.setyobudianto.com/2015/09/pengertian-dasar-pvimpressionfilled.html>

SofyanYamin. (2014). Rahasia Olah Data Lisrel. Jakarta: Mitra Wacana Media.

Speck, P.S., Elliot, M.T., (1997). "Predictors of advertising avoidance in print and broadcast media". Jurnal Advert. 26 (3), 61-76.

Tellis, G.J., (1997). Advertising and Sales Promotion Strategy. Addison-Wesley, USA.

Yang, K.C.C., (2004). "A comparison of attitudes towards Internet advertising among lifestyle segments in Taiwan". Journal Mark Commun. 10 (3), 195-212.

$\mathrm{Yu}$, C.S., (2011). "Construction and validation of an e-lifestyle instrument". Int Res. 21 (3), 214-235. 